\title{
Use of i-BODE index to determine efficacy of pulmonary rehabilitation in COPD patients
}

\author{
Ipek CANDEMIR ${ }^{1}$ \\ PInar ERGUN ${ }^{1}$ \\ Dicle KAYMAZ ${ }^{1}$ \\ Neşe DEMiR ${ }^{1}$
}

1 Pulmonary Rehabilitation and Home Care Center, Ankara Ataturk Chest Diseases and Thoracic Surgery Training and Research Hospital, Ankara, Turkey

${ }^{1}$ Ankara Atatürk Göğüs Hastalıkları ve Göğüs Cerrahisi Eğitim ve Araştırma Hastanesi, Pulmoner Rehabilitasyon ve Evde Bakım Merkezi, Ankara, Türkiye
Cite this arcticle as: Candemir $i$, Ergun $P$, Kaymaz $D$, Demir $N$. Use of $i-B O D E$ index to determine efficacy of pulmonary rehabilitation in COPD patients. Tuberk Toraks 2019;67(2):116-23.

\section{Yazışma Adresi (Address for Correspondence)}

\section{Dr. İpek CANDEMIR}

Ankara Atatürk Göğüs Hastalıkları ve Göğüs Cerrahisi Eğitim ve Araştırma Hastanesi, Pulmoner Rehabilitasyon ve Evde Bakım Merkezi, ANKARA-TÜRKIYE

e-mail: ipekcayli@yahoo.com

CCopyright 2019 by Tuberculosis and Thorax

Available on-line at www.tuberktoraks.org.com

\section{SUMMARY}

Use of i-BODE index to determine efficacy of pulmonary rehabilitation in COPD patients

Introduction: Pulmonary rehabilitation $(P R)$ is well-proven approach on improving dyspnea, exercise intolerance which are two components of BODE index. But, $P R$ is known to have minimal effect on pulmonary function which is another component of BODE index. There are few studies evaluating $P R$ efficacy by using $i-B O D E$ index. Our aim was to evaluate efficacy of $P R$ in patients with chronic obstructive pulmonary disease (COPD) with i-BODE index and to investigate changes in i-BODE index according to GOLD 2011 combined assessment.

Materials and Methods: A total of 228 stable COPD patients who completed a comprehensive 8 week duration $P R$ program were enrolled into this retrospective study.

Results: The patients were with mean age of $63.3 \pm 8.6$ years and mean FEV $\%$ was $38.6 \pm 16.2 \%$. According to combined assessment of COPD, 23 patients were group $A, 30$ patients were $B, 31$ patients were $C$ and 144 patients were $D$. Baseline $i-B O D E$ scores correlated with body compositions, pulmonary function, dyspnea, exercise capacity, psychological status, quality of life, and age. $i$-BODE index score decreased from $4.7 \pm 2.2$ to $3.5 \pm 1.8$ after $P R(p<0.001)$, improved by $26 \%$. Significant improvements were found in dyspnea, quality of life and $i-B O D E$ index in more symptomatic patients (group $B$ and D).

Conclusion: This study highlights that changes in i-BODE scores after PR significantly correlated with improvements in dyspnea, exercise capacity and quality of life. $i-B O D E$ score could be a better predictor of efficacy of $P R$ than some individual variables such as BMI or FEV . Significant improvements in dyspnea sensation, quality of life and $i-B O D E$ index could be seen symptomatic patients in after $P R$.

Key words: Pulmonary rehabilitation; exercise; chronic obstructive pulmonary disease 


\section{ÖZET}

\section{KOAH'lı hastalarda pulmoner rehabilitasyonun etkinliğini belirlemek için i-BODE indeksinin kullanımı}

Giriş: Pulmoner rehabilitasyon (PR)'un, BODE indeksinin iki bileşeni olan egzersiz intoleransı ve dispnenin düzelmesinde kanıtlanmış bir yaklaşımdır. Ancak, PR'nin, BODE indeksinin başka bir bileşen olan solunum fonksiyonuna minimal etkisi olduğu bilinmektedir. $P R$ etkinliğini $i$-BODE indeksi kullanarak değerlendiren az sayıda çalıșma vardır. Amacımız, kronik obstrüktif akciğer hastalı̆̆ı (KOAH) olan hastalarda PR'nin etkinliğini i-BODE indeksiyle değerlendirmek ve GOLD 2011 kombine değerlendirmesine göre i-BODE indeksindeki değişiklikleri araştırmaktı.

Materyal ve Metod: Sekiz haftalık kapsamlı PR programı tamamlayan toplam 228 KOAH tanılı hasta retrospektif çalışmaya dahil edildi.

Bulgular: Hastaların yaş ortalaması $63.3 \pm 8.6$ yıl ve ortalama $F E V_{1} \% 38.6 \pm 16.2$ idi. KOAH'ın kombine değerlendirmesine göre 23 hasta grup A, 30 hasta B, 31 hasta $C$ ve 144 hasta D idi. Bazal i-BODE skorları; vücut kompozisyonları, solunum fonksiyonu, dispne, egzersiz kapasitesi, psikolojik durumla ilişkili yaşam kalitesi ve yaş ile korele olarak izlendi. $i$-BODE indeks skoru PR sonrası \%26'lık farkla $4.7 \pm 2.2^{\prime}$ den $3.5 \pm 1.8^{\prime}$ e düştü ( $p<0.001$ ). Daha semptomatik olan hastalarda (grup $B$ ve $D$ ) dispne, yaşam kalitesi ve $i-B O D E$ indeksinde anlamlı gelişmeler bulundu.

Sonuç: $B u$ çalışma PR sonrası i-BODE skorlarındaki değişikliklerin dispne, egzersiz kapasitesi ve yaşam kalitesindeki düzelmelerle anlamlı bir şekilde ilişkili olduğunu vurgulamaktadır. i-BODE skoru, PR'nin etkinliğinin BMI veya FEV 1 gibi bazı bireysel değişkenlerden daha iyi bir prediktörü olabilir. PR sonrası, semptomatik hastalarda dispne hissi, yaşam kalitesi ve i-BODE indeksinde önemli gelişmeler izlenebilir.

Anahtar kelimeler: Pulmoner rehabilitasyon; egzersiz; kronik obstrüktif akciğer hastalığı

\section{INTRODUCTION}

Chronic obstructive pulmonary disease (COPD) is a common respiratory condition characterized by airflow limitation. It has been mentioned that there are large heterogeneity of patients' characteristics in several studies (1-3). Because of heterogeneity in terms of clinical outcomes, disease severity and progression, the 2011 update of the Global Initiative for Chronic Obstructive Lung Disease (GOLD) proposed a multidimensional clinical evaluation that classifies patients into four groups (A, B, C, and D) according to exacerbation history, level of symptoms, and severity of airflow obstruction (4). Besides the clinical heterogenity, COPD is found to be associated with loss of lean body mass, impaired muscle function and high morbidity and mortality (5). The BODE index, one of the most important mortality predictor and a multidimensional grading scale, composed of body mass index (BMI), airflow obstruction, functional dyspnea as measured by the Modified Medical Research Council (mMRC) dyspnea scale, and exercise capacity, has been developed in an attempt to better assess the severity, disability and prognosis. The BODE index has been found to be better than forced expiratory volume in 1 second $\left(\mathrm{FEV}_{1}\right)$ in predicting the risk of death and hospitalization among patients with COPD $(6,7)$. BODE also includes domains that relate to the quality of life of patients with COPD and has been shown to be sensitive to change with interventions like pulmonary rehabilitation (PR) (8).
It was recently suggested that the incremental shuttle walking test (ISWT) could be substituted for the six minute walking test (6MWT) as an alternative measure of exercise capacity within the index and introduced into the i-BODE score (9). Eventhough field exercise tests, the ISWT and 6MWT are closely related, ISWT is considered to be closer to a maximal exercise test, whereas the 6MWT reflects a more functional exercise performance (10). ISWT correlates well with $\mathrm{VO}_{2}$ max in cardiopulmonary testing (CPET) and has been widely used as a measure of exercise capacity in many clinical studies involving patients with COPD and specifically in studies on PR (11-18). There are few studies evaluating multidisciplinary PR efficacy by using i-BODE index.

In this study, our primary aim was to evaluate the efficacy of PR in COPD patients by using i-BODE index and secondary aim was to investigate the changes in i-BODE index when the patients were classified according to GOLD 2011 combined assessment.

\section{MATERIALS and METHODS}

Two hundred twenty eight stable COPD patients, who completed a comprehensive, outpatient, 8 week duration PR program, were enrolled into this retrospective study. Patients' and instutional review board approvals had been taken before the datas were recorded. Dyspnea sensation was assessed with mMRC scale, quality- of life with St George's Respiratory Questionnaire (SGRQ), exercise capacity with incre- 
mental and endurance shuttle walk test (ISWT, ESWT), psychological status with hospital anxiety and depression scale (HAD) before and after the PR program. Body composition was evaluated by bioelectrical impedance method. BMI and fat free mass index (FFMI) were also calculated.

The PR consisted of a comprehensive, multidisciplinary, hospital based-supervised outpatient program. The program consisted of education (education included disease education, how to control exacerbations, medication advices, bronchial hygiene techniques, and breathing control techniques, energy conservation, relaxation, and dietary advices) exercise training, psychological support, nutritional support. Educational courses were given by two pulmonologists, two physical therapists, a dietician, a respiratory nurse and a psychologist. The rehabilitation program was completely tailored to suit the needs of the individual. According to guideline recommendations, the exercise program was also tailored to the individual and a group of exercises was chosen for each patient according to their ability to tolerate exercise and their disease severity. The exercise training and the sessions included cycle ergometer and treadmill training (15 min each), strength training of both upper and lower extremities (5-10 $\mathrm{min})$, and therapies for breathing and relaxation (15-20 min each) for a total of 70-90 min/day. Both workload for cycling and walking speed for treadmill ergometer were calculated from ISWT results using formulations and BORG dyspnea scores were also used for prescribing exercise (4-6). Patients were trained at $50 \%$ of the peak workload on cycle ergometer and $60-85 \%$ of $\mathrm{VO}_{2}$ peak on treadmill (19). Intensity of exercise was increased according to the progress of individual patient. Physiotherapists provided close supervision and heart rate, blood pressure and oxygen saturation were monitored during the training sessions. Supplemental oxygen was administered to a level of oxygen saturation above $90 \%$.

\section{Statistical Analysis}

SPSS version 18.0 (SPSS, Inc., NY, USA) for Microsoft Windows (Microsoft Corporation, Redmond, Washington) was used for analysis. Data are expressed as mean \pm SD unless stated otherwise. Shapiro-Wilks test was used for testing distribution of the data. The paired t-test was used for variables with normal distribution and the Wilcoxon signed-rank test was used for variables without normal distribution. For correlation analysis, Pearson correlation analysis was used for variables with normal distribution and Spearman correlation was used when the variables distrubuted non-normally. Kruskal Wallis test was performed to compare the parameters distrubuted non-normally among groups. Post hoc analysis were applied to identify the differences between groups. Statistical significance was set to a $p$ value $<0.05$.

\section{Allocation of Points for the i-BODE Index}

In order to allocate points for the i-BODE index, it has been used before by Williams et al. (9). How the cut-off values for the 6MWT were assigned in the original BODE validation is not clear. Patients received points ranging from 0 (the least disabled patients who walked more than $250 \mathrm{~m}$ on the ISWT) to 3 (the most disabled patients who walked $80 \mathrm{~m}$ or less on the ISWT). An i-BODE score was then calculated for each patient (using the values for each component as they were at the time of initial PR assessment and after PR) and using the original BODE weightings and scoring system for the $\mathrm{FEV}_{1} \%$ predicted, BMI and modified MRC scale. We replaced distance walked on the ISWT for the 6MWT distance with the allocation of points as described above:

\begin{tabular}{|c|c|c|c|c|}
\hline Variable & 0 points & 1 points & 2 points & 3 points \\
\hline $\mathrm{FEV}_{1} \%$ predicted & $\geq 65$ & $50-64$ & $36-49$ & $\leq 35$ \\
\hline ISWT (meter) & $\geq 250$ & $150-249$ & $80-149$ & $<80$ \\
\hline mMRC scale & $0-1$ & 2 & 3 & 4 \\
\hline BMI kg/m² & $>21$ & $\leq 21$ & & \\
\hline
\end{tabular}

\section{RESULTS}

The mean age of 228 patients with COPD was $63.3 \pm$ 8.6 years. One hundred and eighty nine $(80.3 \%)$ of them were males. Recorded parameters before and after PR, are given in Table 1. Mean FEV 1 predicted was $38.6 \pm 16.2 \%$. Two $(0.9 \%)$ of them were stage 1 , $50(21.9 \%)$ were stage $2,92(40.4 \%)$ were stage 3 and $84(36.8 \%)$ were stage 4 according GOLD post-bronchodilator spirometric criteria. According to 2011 combined assessment of COPD, 23 patients were group $A, 30$ patients were $B, 31$ patients were $C$ and 144 patients were $D$.

Baseline i-BODE was negatively correlated with FVC $\%(p=0.000, r=-0.624), F^{2} V_{1} \%(p=0.000, r=$ -0.679), BMI $(p=0.000, r=-0.306)$, FFMI $(p=0.000$, $r=-0.386)$, ISWT $(p=0.000, r=-0.782)$, ESWT $(p=$ 
Table 1. Recorded parameters before and after pulmonary rehabilitation (PR)

\begin{tabular}{|lccc|} 
& Before PR & After PR & p \\
\hline BMI $\left(\mathrm{kg} / \mathrm{m}^{2}\right)$ & $25.5 \pm 5.9$ & $25.7 \pm 5.8$ & $\mathbf{0 . 0 0 1}$ \\
FFMI $\left(\mathrm{kg} / \mathrm{m}^{2}\right)$ & $19.0 \pm 2.7$ & $19.0 \pm 2.4$ & 0.251 \\
mMRC & $2.1 \pm 0.8$ & $1.3 \pm 0.7$ & $\mathbf{0 . 0 0 0}$ \\
SGRQ total & $63.2 \pm 17$ & $31.9 \pm 12.7$ & $\mathbf{0 . 0 0 0}$ \\
Anxiety score & $9.0 \pm 2.3$ & $5.6 \pm 2.4$ & $\mathbf{0 . 0 0 0}$ \\
Depression score & $9.2 \pm 2.7$ & $6.0 \pm 3.3$ & $\mathbf{0 . 0 0 0}$ \\
ISWT $(\mathrm{m})$ & $218 \pm 114$ & $278 \pm 121$ & $\mathbf{0 . 0 0 0}$ \\
ESWT (min) & $7.4 \pm 6.5$ & $12.6 \pm 7.6$ & $\mathbf{0 . 0 0 0}$ \\
i-BODE index & $4.7 \pm 2.2$ & $3.5 \pm 1.8$ & $\mathbf{0 . 0 0 0}$
\end{tabular}

BMI: Body mass index, FFMI: Fat free mass index, Mmrc: Modified medical research council, SGRQ: St George's respiratory questionnaire, ISWT: Incremental shuttle walk test, ESWT: Endurance shuttle walk test, HAD: Hospital anxiety and depression scale, i-BODE: Body mass index,

obstruction (forced expiratory volume in $1 \mathrm{sec}$ ), mMRC dyspnea scale, exercise capacity (incremental shuttle walk test).

0.000, $r=-0.582)$, where a positive correlation was found with anxiety score $(p=0.012, r=0.167)$, SGRQ total $[p=0.000, r=-0.551$ (Figure 1)], $\operatorname{mMRC}(p=$ $0.000,0.801)$ and age $(p=0.000, r=0.283)$.

According to GOLD 2011 combined assessment of COPD, baseline i-BODE index, mMRC scale, SGRQ total score, ISWT and ESWT values were significantly different between groups (all values' $p=0.000$ ). Baseline i-BODE index scores were significantly different between the groups except in group B and C (Figure 2). Baseline SGRQ total scores of patients were significantly worse in Group B and D. Patients in group D had significantly decreased ISWT and ESWT than other groups (Table 2).

i-BODE index score decreased from $4.7 \pm 2.2$ to 3.5 \pm 1.8 after PR $(p=0.000)$, improved by $25.5 \%$. Change in $\mathrm{i}-\mathrm{BODE}$ index correlated with changes in $\mathrm{mMRC}(p=0.000, r=0.472)$, SGRQ total $(p=0.000$, $r=0.350)$, ISWT $(p=0.000, r=-0.300)$, ESWT $(p=$ $0.000, r=-0.297)$.

Improvement after PR was assessed according to GOLD 2011 combined assessment of COPD. Changes in $m$ MRC $(p=0.000), S G R Q$ total scores $(p=0.001)$, $\mathrm{i}-$ BODE index $(\mathrm{p}=0.000$ - Figure 3$)$ were statistically significant between groups. Significant improvements were found in dyspnea sensation, quality of life and i-BODE index in more symptomatic patients such as in Group B and D. [Differences between group $A$ and $\mathrm{B}, \mathrm{A}$ and $\mathrm{D}, \mathrm{B}$ and $\mathrm{C}, \mathrm{C}$ and $\mathrm{D}$ in $\mathrm{mMRC}$ score, group $A$ and $D, C$ and $D$ in SGRQ score, group $A$ and $B, A$ and $\mathrm{D}, \mathrm{B}$ and $\mathrm{C}, \mathrm{C}$ and $\mathrm{D}$ in $\mathrm{i}-\mathrm{BODE}$ index were statistically significant (Table 3)].

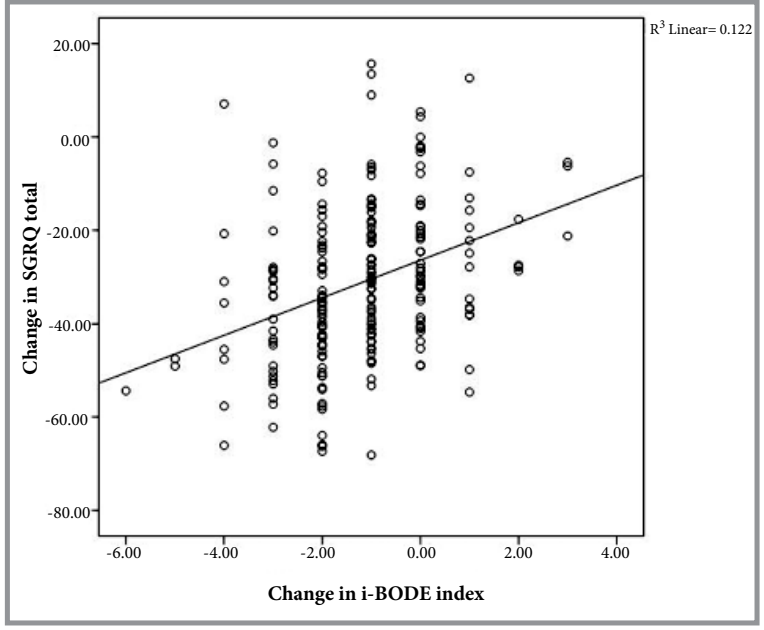

Figure 1. Correlation between change in SGRQ total and change in i-BODE index.

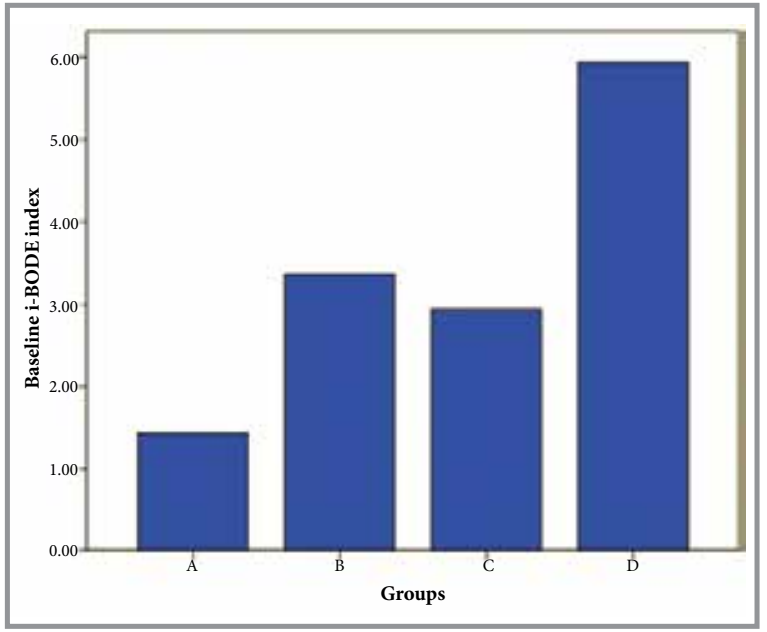

Figure 2. Baseline i-BODE index according to groups. 
Table 2. Baseline values of patients that grouped according to the global initiative for chronic obstructive lung disease (GOLD) combined assessment of COPD

\begin{tabular}{lcccccccc} 
GOLD $(\mathbf{n})$ & BMI & mMRC & SGRQ total & Anxiety & Depression & ISWT & ESWT & i-BODE \\
\hline A (23) & $27 \pm 6$ & $2.0 \pm 0$ & $46 \pm 13$ & $8.3 \pm 2.4$ & $8.3 \pm 2.3$ & $303 \pm 105$ & $13 \pm 6$ & $1.4 \pm 1.2$ \\
B (30) & $29 \pm 5$ & $3.2 \pm 0.5$ & $64 \pm 15$ & $9.0 \pm 2.1$ & $9.9 \pm 2.1$ & $241 \pm 114$ & $9 \pm 6$ & $3.3 \pm 1.5$ \\
C (31) & $25 \pm 5$ & $2.0 \pm 0.2$ & $50 \pm 15$ & $8.2 \pm 2.1$ & $8.2 \pm 2.2$ & $316 \pm 93$ & $10 \pm 6$ & $2.9 \pm 0.9$ \\
D (144) & $24 \pm 5$ & $3.5 \pm 0.6$ & $68 \pm 15$ & $9.2 \pm 2.3$ & $9.3 \pm 2.2$ & $179 \pm 98$ & $5 \pm 5$ & $5.9 \pm 1.6$
\end{tabular}

BMI: Body mass index, Mmrc: Modified medical research council, SGRQ: St George's respiratory questionnaire, ISWT: Incremental shuttle walk test, ESWT: Endurance shuttle walk test, HAD: Hospital anxiety and depression scale, i-BODE: Body mass index, obstruction (forced expiratory volume in $1 \mathrm{sec}$ ), mMRC dyspnea scale, exercise capacity (incremental shuttle walk test).

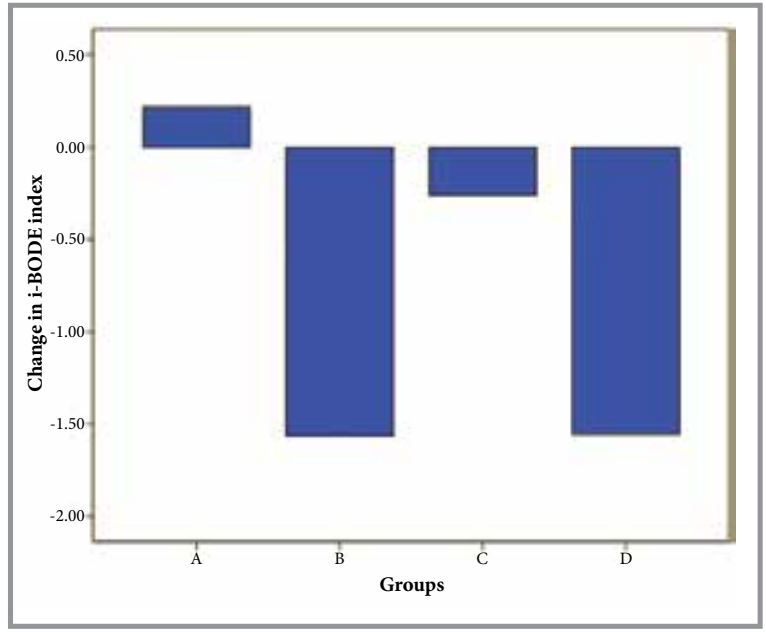

Figure 3. Change in i-BODE index according to groups.

\section{DISCUSSION}

The present study showed that baseline i-BODE scores correlated with body compositions, pulmonary functions, dyspnea sensation, exercise capacity, psychological status, quality of life, and age. After PR, improvements in i-BODE correlated with improvements in dyspnea sensation, exercise capacity and quality of life. It was also found that i-BODE could a better predictor of efficacy of PR than some individual variables such as $\mathrm{BMI} \mathrm{FEV}_{1}$ and symptomatic patients had significant improvements in dyspnea sensation, quality of life and i-BODE index after PR.

PR improves dyspnea, exercise capacity, healthcare resource utilisation and has minimal effect on lung function (8). Two of these outcomes, dyspnea and exercise capacity, are components of the BODE index. It has been shown in a previous study, BODE index was found to be improved by $19 \%$ and decreased from $5 \pm 1.5$ to $4.1 \pm 1.6$ in 116 COPD patients after PR. In our study i-BODE index score decreased from $4.7 \pm 2.2$ to $3.5 \pm 1.8$ after $\mathrm{PR}$, improved by $26 \%$. As such, the BODE index could be used to evaluate the effect of PR. It was also shown that PR improves health status in COPD patients. The disease specific SGRQ is perhaps the most widely used and better tested of those instruments available for patients with COPD. It has been proven to be responsive to several interventions in COPD such as pharmacological agents, pulmonary rehabilitation and lung volume reduction (20-23). In a study, it was found that SGRQ total score correlated

Table 3. Changes in values of patients that grouped according to the global initiative for chronic obstructive lung disease (GOLD) combined assessment of COPD

\begin{tabular}{|c|c|c|c|c|c|c|c|c|}
\hline GOLD (n) & $\Delta \mathrm{BMI}$ & $\triangle \mathrm{mMRC}$ & $\Delta S G R Q$ total & $\Delta$ Anxiety & $\Delta$ Depression & $\Delta$ ISWT & $\Delta \mathrm{ESWT}$ & $\triangle \mathrm{i}$-BODE \\
\hline $\mathrm{A}(23)$ & $0.12 \pm 1.18$ & $-0.3 \pm 0.5$ & $-22 \pm 15$ & $-3.2 \pm 2.6$ & $-4.2 \pm 2.6$ & $91 \pm 71$ & $5.3 \pm 6$ & $0.2 \pm 1.7$ \\
\hline B (30) & $0.23 \pm 0.99$ & $-1 \pm 0.5$ & $-32 \pm 14$ & $-3.8 \pm 2$ & $-3.1 \pm 3.4$ & $61 \pm 61$ & $6.7 \pm 7.3$ & $-1.5 \pm 1.7$ \\
\hline C (31) & $0.22 \pm 0.76$ & $-0.3 \pm 0.5$ & $-22 \pm 16$ & $-2.8 \pm 2.6$ & $-3 \pm 2.7$ & $54 \pm 45$ & $4.6 \pm 5.4$ & $-0.2 \pm 0.9$ \\
\hline D (144) & $0.23 \pm 0.96$ & $-0.9 \pm 0.5$ & $-34 \pm 15$ & $-3.4 \pm 2.3$ & $-3.1 \pm 2.4$ & $55 \pm 58$ & $5.1 \pm 6.7$ & $-1.5 \pm 1.1$ \\
\hline
\end{tabular}

BMI: Body mass index, Mmrc: Modified medical research council, SGRQ: St George's respiratory questionnaire, ISWT: Incremental shuttle walk test, ESWT: Endurance shuttle walk test, HAD: Hospital anxiety and depression scale, i-BODE: Body mass index, obstruction (forced expiratory volume in $1 \mathrm{sec}$ ), $\mathrm{mMRC}$ dyspnea scale, exercise capacity (incremental shuttle walk test). 
better with BODE index than with $\mathrm{FEV}_{1} \%$ (23). Correlation was found between $\mathrm{i}-\mathrm{BODE}$ index and SGRQ and after PR improvements in i-BODE index and SGRQ were also correlated in our study. In COPD patients, another factor that effects the quality of life is psychological status. Depression is frequently seen in patients with COPD. The presence of respiratory symptoms causes substantial anxiety and depression. It was found that anxiety and depression themselves were risk factors of increased mortality (24). In most studies FEV 1 was a bad predictor of anxiety and depression $(25,26)$. Funk et al., in a study of 122 in-patients with COPD, reported that the BODE index better reflects the prevalence of depression, as opposed to the GOLD classification, which is based on the severity of lung function (27). In our study, however there was no significant correlation between depression score and $\mathrm{i}-\mathrm{BODE}$, significant correlation was found between anxiety and $\mathrm{i}$-BODE. Another correlation found between i-BODE and age in our study. It has been shown that BODE index could had been applied in to an elderly COPD patient and had been valuable prognostic indicator for COPD patients of any age in previous study (28).

The 2011 revision of the GOLD strategy document presented a new $A B C D$ group classification of COPD which intended to provide a better understanding of the impact of the disease on an individual patient than spirometric GOLD grades. Symptom burden is divided into low (A and $C$ ) and high (B and D), whereas airflow limitation and/or exacerbation history separates A from C, and B from D. Regarding the latter, patients should be placed in the group that gives the highest exacerbation risk according to airflow limitation $\left(\mathrm{ppFEV}_{1}<50\right.$ ) or exacerbation history ( $\geq 2$ last year) (GOLD). Nishimura et al. found significant correlations between the GOLD 2011 A-B-C-D classification with maximal exercise capacity evaluated by the peak volume of oxygen intake $\left(\mathrm{VO}_{2}\right)$, as well as with the modified BODE index (29). However, the authors did not present the correlation coefficient values and only highlighted that the peak $\mathrm{VO}_{2}$ was stratified by the GOLD 2011 classification, showing a severity gradient from GOLD A to GOLD D, although no difference between groups $B$ and $C$ was observed as smiliar to our study. In a recent study, when analyzing the functionality assessed by the median of 6MWT (expressed as percentage of predicted values) between groups B-C-D and grades II-III-IV, both classifications discriminated group D from B and C and grade 4 from 3 and 2, without significant differences among the other groups (30). In this study, patients in group $\mathrm{D}$ had significantly lower exercise capacity than other groups.

In a study with 150 COPD patients, it was found that the relationship between the GOLD 2011 classification and the psychological status evaluated by the HADS was not significant. The anxiety and depression scores on the HADS were worse in the GOLD B and GOLD D groups than in GOLD A and GOLD C. It was thought to be relationship between mood states and sypmtoms (29). In this study group B and D had worse scores of HADS than group $\mathrm{A}$ and $\mathrm{C}$ but it was not statiscally different. In a study it was found that GOLD B and GOLD D had the greatest prevalence of cardiac morbidities, diabetes, and depression in addition to the lowest employment levels, self-efficacy scores, and levels of physical activity. Patients with GOLD A had the least impaired disease-specific and generic HR-QoL, followed by patients with GOLD C, GOLD B, and GOLD D for all HR-QoL measures. Patients with GOLD $C$ had a better quality of life than those with GOLD B. Patients with GOLD A had the lowest costs while patients with GOLD D had the highest (31). Several studies demonstrated that the unidimensional and multidimensional GOLD 2011 classifications do not differ significantly in terms of ability to predict hospitalization and mortality, except for quality of life in which GOLD A-B-C-D is more closely associated with this outcome than GOLD I-IIIII-IV due to the nature of the A-B-C-D classification involving a measure of quality of life (30). In this study more symptomatic patients such as in group $B$ and $D$ had been found to have worse dyspnea sensation and quality of life than group $\mathrm{A}$ and $\mathrm{C}$. It is also important to show that significant improvements were found in dyspnea sensation, quality of life and i-BODE index in patients of group B and D after PR so the assessment of PR efficacy by using i-BODE index in more sympthomatic patients would be more accurate.

\section{CONCLUSION}

This study showed that, i-BODE scores correlated not only with all the component of the itself but also correlated with psychological status, quality of life, and age. i-BODE index was found to be responsive to PR and after PR, improvements in i-BODE correlated with improvements in dyspnea sensation, exercise capacity and quality of life. This result was thought 
that $\mathrm{i}-\mathrm{BODE}$ could a better predictor of efficacy of PR than some individual variables such as $B M I, F E V_{1}$. Symptomatic patients had significant improvements in dyspnea sensation, quality of life and i-BODE index after PR.

\section{CONFLICT of INTEREST}

All authors have no conflict of interests.

\section{AUTHORSHIP CONTRIBUTIONS}

\section{Concept/Design: iC, PE, DK}

Analysis/Interpretation: IC, ND, PE

Data Acquisition: IC, DK, ND

Writting: IC, PE

Critical Revision: All of authors.

Final Approval: All of authors.

\section{REFERENCES}

1. Bestall JC, Paul EA, Garrod R, Garnham R, Jones PW Wedzicha JA. Usefulness of the Medical Research Council (MRC) dyspnoea scale as a measure of disability in patients with chronic obstructive pulmonary disease. Thorax 1999;54:581-6.

2. Jones PW, Harding G, Berry P, Wiklund I, Chen WH, Kline Leidy N. Development and first validation of the COPD assessment test. Eur Respir J 2009;34:648-54.

3. Lange $P$, Marott IL, Vestbo J, Olsen KR, Ingebrigtsen TS, Dahl $M$, et al. Prediction of the clinical course of chronic obstructive pulmonary disease, using the new GOLD classification: a study of the general population. Am J Respir Crit Care Med 2012; 186:975-81.

4. Han MK, Muellerova H, Curran-Everett D, Dransfield MT, Washko GR, Regan EA, et al. GOLD 2011 disease severity classification in COPD Gene: a prospective cohort study. Lancet Respir Med 2013;1:43-50.

5. Ong KC, Earnest A, Lu SJ. A multidimensional grading system (BODE index) as predictor of hospitalization for COPD. Chest 2005; 128:3810-6.

6. Parr DG. Patient phenotyping and early disease detection in chronic obstructive pulmonary disease. Proc Am Thorac Soc 2011;8:338-49.

7. Agusti A, Calverley PM, Celli B, Coxson HO, Edwards $L D$, Lomas DA, et al. Characterisation of COPD heterogeneity in the ECLIPSE cohort. Respir Res 2010;11:122.

8. Cote CG, Celli BR. Pulmonary rehabilitation and the BODE index in COPD. Eur Respir J 2005;26:630-6.

9. Williams JE, Green RH, Warrington V, Steiner MC, Morgan $M D$, Singh SJ. Development of the i-BODE: Validation of the incremental shuttle walking test within the BODE index. Respir Med 2012;106:390-6.
10. Onorati P, Antonucci R, Valli G, Berton E, De Marco $F$, Serra $P$, et al. Non-invasive evaluation of gas exchange during a shuttle walking test vs. a 6-min walking test to assess exercise tolerance in COPD patients. Eur J Appl Physiol 2003;89:331-6.

11. Singh SJ, Morgan MD, Scott S, Walters D, Hardman AE. Development of a shuttle walking test of disability in patients with chronic airways obstruction. Thorax 1992;47:1019-24.

12. Singh SJ, Morgan MD, Hardman AE, Rowe C, Bardsley PA. Comparison of oxygen uptake during a conventional treadmill test and the shuttle walking test in chronic airflow limitation. Eur Respir J 1994;7:2016-20.

13. Arnardottir RH, Emtner $M$, Hedenstrom $H$, Larsson $K$, Boman G. Peak exercise capacity estimated from incremental shuttle walking test in patients with COPD: a methodological study. Respir Res 2006;7:127.

14. Egan C, Deering BM, Blake C, Fullen BM, McCormack $N M$, Spruit MA, et al. Short term and long term effects of pulmonary rehabilitation on physical activity in COPD. Respir Med 2012;106:1671-9.

15. Albores J, Marolda C, Haggerty M, Gerstenhaber B, Zuwallack $R$. The use of a home exercise program based on a computer system in patients with chronic obstructive pulmonary disease. J Cardiopulm Rehabil Prev 2013;33:47-52.

16. Garrod R, Ford K, Daly C, Hoareau C, Howard M, Simmonds C. Pulmonary rehabilitation: analysis of a clinical service. Physiother Res Int 2004;9:111-20.

17. Spencer LM, Alison JA, McKeough ZJ. Do supervised weekly exercise programs maintain functional exercise capacity and quality of life, twelve months after pulmonary rehabilitation in COPD? BMC Pulm Med 2007;7:7.

18. Liu WT, Wang CH, Lin HC, Lin SM, Lee KY, Lo YL. Efficacy of a cell phone-based exercise programme for COPD. Eur Respir J 2008;32:651-9.

19. Garvey C, Bayles MP, Hamm LF, Hill K, Holland A, Limberg $T M$, et al. Pulmonary Rehabilitation Exercise Prescription in Chronic Obstructive Pulmonary Disease: Review of Selected Guidelines: AN OFFICIAL STATEMENT FROM THE AMERICAN ASSOCIATION OF CARDIOVASCULAR AND PULMONARY REHABILITATION. I Cardiopulm Rehabil Prev 2016;36:75-83.

20. Bursas V, Hodder R, Miravitlles M, Korducki L, Towse L, Kesten $S$. Health outcomes following treatment for six months with once daily tiotropium compared with twice daily salmeterol in patients with COPD. Thorax 2003;58:399-404.

21. Fishman A, Martinez $F$, Naunheim K, Piantadosi S, Wise $R$, Ries $A$, et al. A randomized trial comparing lung-volumereduction surgery with medical therapy for severe emphysema. N Engl J Med 2003;348:2059-73. 
22. Ries AL, Kaplan RM, Limberg TM, Prewitt LM. Effects of pulmonary rehabilitation on physiologic and psychosocial outcomes in patients with chronic obstructive pulmonary disease. Ann Intern Med 1995;122:823e32.

23. Güell R, Casan P, Belda J, Sangenis M, Morante F, Guyatt $\mathrm{GH}$, et al. Long-term effects of outpatient rehabilitation of COPD: a randomized trial. Chest 2000;117:976-83.

24. Ostir GV, Goodwin JS. High anxiety is associated with an increased risk of death in an older tri-ethnic population. I Clin Epidemiol 2006;59:534-40.

25. Ng TP, Niti M, Tan WC, Cao Z, Ong KC, Eng P. Depressive symptoms and chronic obstructive pulmonary disease: effect on mortality, hospital readmission, symptom burden, functional status, and quality of life. Arch Intern Med 2007; 167:60-7.

26. Hill K, Geist R, Goldstein RS, Lacasse Y. Anxiety and depression in end-stage COPD. Eur Respir J 2008;31:667-77.

27. Ries AL. Impact of chronic obstructive pulmonary disease on quality of life: the role of dyspnea. Am J Med 2006; 19:12-20.
28. Pedone C, Scarlata S, Forastiere F, Bellia V, Antonelli Incalzi $R$. BODE index or geriatric multidimensional assessment for the prediction of very-long-term mortality in elderly patients with chronic obstructive pulmonary disease? A prospective cohort study. Age Ageing 2014;43:553-8.

29. Nishimura $K$, Oga $T$, Tsukino $M$, Hajiro $T$, Ikeda $A$, Jones $P W$. Reanalysis of the Japanese experience using the combined COPD assessment of the 2011 GOLD classification. Respir Investig 2014;52:129-35.

30. Moreira GL, Donária L, Furlanetto KC, Paes T, Sant'Anna T, Hernandes NA, et al. GOLD B-C-D groups or GOLD II-III$I V$ grades: Which one better reflects the functionality of patients with chronic obstructive pulmonary disease? Chron Respir Dis 2015;12:102-10.

31. Boland MR, Tsiachristas A, Kruis AL, Chavannes NH, Rutten-van Mölken MP. Are GOLD ABCD groups better associated with health status and costs than GOLD 1234 grades? A cross-sectional study. Prim Care Respir I 2014;23:30-7. 